\title{
1 Faulting and hydration of the Juan de Fuca plate system
}

2 Mladen R. Nedimović ${ }^{1,3}$, DelWayne R. Bohnenstiehl ${ }^{2,3}$, Suzanne M. Carbotte ${ }^{3}$, J. Pablo

3 Canales $^{4}$ and Robert P. Dziak ${ }^{5}$

4

$5{ }^{1}$ Department of Earth Sciences, Dalhousie University, Room 3006, Life Sciences Centre,

6 Halifax, NS, B3H 4J1, Canada

$7{ }^{2}$ Department of Marine, Earth and Atmospheric Sciences, North Carolina State

8 University, Campus Box 8208, Raleigh, NC 27695, USA

$9{ }^{3}$ Lamont-Doherty Earth Observatory of Columbia University, 61 Route 9W, P. O. Box

10 1000, Palisades, NY 10964-8000, USA

$11{ }^{4}$ Department of Geology and Geophysics, MS\#24, Woods Hole Oceanographic

12 Institution, 360 Woods Hole Rd., Woods Hole, MA 02543, USA

$13{ }^{5}$ Hatfield Marine Science Center, Oregon State University and NOAA, 2030 Marine

14 Science Dr., Newport, OR 97365, USA

15 Corresponding author

16 M. R. Nedimović

17 Department of Earth Sciences

18 Life Sciences Centre

19 Dalhousie University

20 Edzell Castle Circle, Halifax

21 NS, B3H 4J1, Canada

22 Telephone: 902-494-4524

23 Fax: 902-494-6889

24 E-mail: mladen@dal.ca 


\section{Abstract}

26 Multichannel seismic observations provide the first direct images of crustal scale normal

27 faults within the Juan de Fuca plate system and indicate that brittle deformation extends

28 up to $\sim 200 \mathrm{~km}$ seaward of the Cascadia trench. Within the sedimentary layering steeply

29 dipping faults are identified by stratigraphic offsets, with maximum throws of $110 \pm 10 \mathrm{~m}$

30 found near the trench. Fault throws diminish both upsection and seaward from the trench.

31 Long-term throw rates are estimated to be $13 \pm 2 \mathrm{~mm} / \mathrm{kyr}$. Faulted offsets within the

32 sedimentary layering are typically linked to larger offset scarps in the basement

33 topography, suggesting reactivation of the normal fault systems formed at the spreading

34 center. Imaged reflections within the gabbroic igneous crust indicate swallowing fault

35 dips at depth. These reflections require local alteration to produce an impedance contrast,

36 indicating that the imaged fault structures provide pathways for fluid transport and

37 hydration. As the depth extent of imaged faulting within this young and sediment

38 insulated oceanic plate is primarily limited to approximately Moho depths, fault-

39 controlled hydration appears to be largely restricted to crustal levels. If dehydration

40 embrittlement is an important mechanism for triggering intermediate-depth earthquakes

41 within the subducting slab, then the limited occurrence rate and magnitude of intraslab

42 seismicity at the Cascadia margin may in part be explained by the limited amount of

43 water imbedded into the uppermost oceanic mantle prior to subduction. The distribution

44 of submarine earthquakes within the Juan de Fuca plate system indicates that propagator

45 wake areas are likely to be more faulted and therefore more hydrated than other parts of

46 this plate system. However, being largely restricted to crustal levels, this localized

47 increase in hydration generally does not appear to have a measurable effect on the

48 intraslab seismicity along most of the subducted propagator wakes at the Cascadia

49 margin.

50 Keywords: Juan de Fuca plate system; seismic reflection imaging; faulting; hydration;

51 earthquakes. 


\section{Introduction}

Oceanic plates carry physically and chemically bound water into subduction

54 zones (e.g., Peacock, 1990; Meade and Jeanloz, 1991; Moore and Vrolijk, 1992; Ranero

55 et al., 2003). As the subducting oceanic plates descend, and the pressure and temperature

56 rise with the increasing depth, the water stored in the plates is gradually released through

57 a series of dehydration reactions (e.g., Meade and Jeanloz, 1991; Kirby et al., 1996;

58 Peacock, 2001, Hacker et al., 2003a,b). This free water is believed to strongly affect a

59 number of processes important to natural hazard studies. The released water promotes

60 partial melting responsible for arc magmatism (Tatsumi and Eggins, 1995; Kirby et al.,

61 1996), can affect the mechanical characteristics of an interplate interface (Shipley et al.,

62 1994; Nedimović et al., 2003a; Kodaira et al., 2004), and induces intraslab earthquakes at

63 intermediate depths ( $\sim 50-300 \mathrm{~km})$ (Raleigh and Paterson, 1965; Meade and Jeanloz,

64 1991; Kirby et al., 1996).

65 Significant effort has therefore been directed toward understanding dehydration

66 processes during subduction, with particular emphasis on the influence these processes

67 may have on the depth-distribution of intraslab seismicity (Meade and Jeanloz, 1991;

68 Peacock, 2001; Hacker et al, 2003a,b; Jung et al., 2004). To fully evaluate the importance

69 of slab dehydration, however, it also is necessary to constrain the amount of water bound

70 in the slab when it is subducted at the trench (Ranero et al., 2003). We focus our effort on

71 determining the penetration depth and relative volume extent of oceanic slab hydration

72 offshore Cascadia margin. For this purpose, we process $\sim 1500 \mathrm{~km}$ of ridge-flank multi-

73 channel seismic (MCS) data collected in 2002 during the EW0207 cruise and compile a

74 database of seismic reflection profiles from all earlier crustal scale MCS surveys

75 (streamers $2.4 \mathrm{~km}$ or longer) across the Juan de Fuca plate system. The spatial

76 distribution of the MCS lines examined is shown in Fig. 1, along with magnetic

77 isochrones (Wilson, 2002) and the locations of Cascadia margin earthquakes believed to 
78 be spatially restricted to the Juan de Fuca plate and subducting slab (Fox et al., 1994;

79 McCrory et al., 2004).

\section{2. Study area}

81 The study area shown in Fig. 1, located offshore western North America,

82 encompasses the Juan de Fuca ridge and plate system (Explorer, Juan de Fuca and Gorda

83 ridges and plates), Cascadia deformation front, Nootka fault, and Sovanco and Blanco

84 fracture zones. The Juan de Fuca ridge system, a NNE-oriented intermediate-rate

85 spreading center, is located at the boundary between the Pacific plate and the Juan de

86 Fuca plate system. The full spreading rate along the Juan de Fuca ridge is $56 \mathrm{~mm} / \mathrm{yr}$, and

$8756 \mathrm{~mm} / \mathrm{yr}$ and less along the Explorer and Gorda ridges (e.g., Wilson, 1993). The

88 Cascadia deformation front marks the surface trace of the interface between the Juan de

89 Fuca and North America plates. The Nootka fault is the boundary between the Explorer

90 and the Juan de Fuca plates, and Blanco and Sovanco fracture zones separate parts of the

91 Juan de Fuca plate system from the Pacific plate.

92 Both the western and eastern flanks of the Juan de Fuca ridge system are crossed

93 by propagator wakes but otherwise show prominent differences indicating that they are

94 evolving in a markedly different way due to distinct sedimentary and volcanic histories.

95 Seamounts, which are found primarily on the Pacific plate, occur as isolated edifices and

96 in chains, several of which lie close to and intersect the Juan de Fuca ridge axis (Davis

97 and Karsten, 1986). Sediments covering the eastern Juan de Fuca ridge flank are up to a

98 few kilometers thick at the northern Cascadia subduction deformation front and thin

99 toward the ridge axis and southward away from the dominant source of terrigenous

100 sediment (Nedimović et al., 2008). The western Juan de Fuca ridge flank is more sparsely

101 sedimented, although sediment cover generally increases to the north where significant

102 sediment accumulation is confined to mini-basins between large basement outcrops. The 
103 enhanced accumulation of sediment on the eastern flank is in large part caused by the

104 morphology of the Juan de Fuca ridge, with its cooling and subsiding flanks forming

105 basin-like depositional environments and its elevated axial region acting as a barrier that

106 inhibits the transport of terrigenous sediment to the western flank.

\section{3. Reflection imaging}

Summary information and corresponding references that describe the MCS data

109 used in this study are provided in Table 1. The prestack processing strategy adopted for

110 the EW0207 MCS data consisted of: Standard straight-line CMP bin geometry; F-K and

111 bandpass (2-7-100-125 Hz) filtering to remove the low frequency cable noise; amplitude

112 correction for geometrical spreading; surface consistent minimum phase predictive

113 deconvolution to balance the spectrum and remove short period multiples; surface

114 consistent amplitude correction to correct for anomalous shot and receiver-group

115 amplitudes not related to wave propagation; trace editing; velocity analysis using the

116 velocity spectrum method; normal moveout and dip moveout corrections to align signal

117 for stacking; and CMP mute to remove overly stretched data. Crossdip moveout

118 correction (Nedimović et al., 2003b) was not required because streamer feathering was

119 small $\left(<10^{\circ}\right)$ and structural crossdip negligible. The prepared prestack data, with and

120 without the automatic gain control, were then stacked (averaged). The poststack

121 processing included seafloor mute, primary multiple mute to reduce migration noise,

122 bandpass filtering (2-7-100-125 Hz), and time migration to collapse diffractions and

123 position the recorded reflection events to their true subsurface locations. To improve

124 imaging within the oceanic plate below the upper crust, the late travel time data were

125 additionally bandpass filtered at 2-7-20-40 Hz and mildly coherency filtered.

126 Analyzed seismic images from field programs other than the 2002 Juan de Fuca

127 cruise were formed earlier by other researchers in a similar way as described for the 
128 EW0207 cruise. Specific details about the processing stream are provided in Calvert and

129 Clowes (1991) for the 1985 Frontier Geoscience project, in Calvert (1996) for the 1989

130 ODP Leg 146 site survey offshore Vancouver Island, in MacKay et al. (1992) for the

1311989 ODP Leg 146 site survey offshore Oregon, in Flueh et al. (1998) for the 1996

132 Orwell project, and in Gulick et al. (1998) for the 1994 Mendocino Triple Junction

133 experiment. The 1994 Gorda Rise and Cape Blanco data were processed only to near-

134 offset brute stacks (Brocher et al., 1995; http://www.ig.utexas.edu/sdc/cruise.php?

135 cruiseIn=ew9413). This processing included: trace edit, amplitude recovery, bandpass

136 filter, CMP sort, normal moveout, stretch mute and stack. From the various survey

137 campaigns described here only some of the Orwell project profile data, although

138 collected using the shortest streamer $(2.4 \mathrm{~km})$ with the smallest number of channels (48),

139 were prestack depth processed (Flueh et al., 1998).

$140 \quad$ 4. Characterization of faulting

141 Analysis of the compiled database of seismic reflection images (Fig. 1) resulted in

142 an outline of the Juan de Fuca plate region of extension or transtension, where normal

143 faulting is observed (Fig.1). The faulting appears nearest to the ridge axis at the northern

144 end of the Juan de Fuca plate but the width of the faulted zone seems to increase

145 southward along the trench, reaching a maximum of over $200 \mathrm{~km}$ near the Blanco

146 fracture zone. Both Explorer and Gorda plates experience deformation throughout, as

147 indicated by the seismicity (Fig. 1). However, seismic reflection constraints on the extent

148 of normal faulting in these two areas are rather limited due to the lack of profile coverage

149 or insufficient image resolution.

150 In Fig. 2 we show for the first time a reflection image of faults within the Juan de

151 Fuca plate system that extend all the way through the sediments and crust to about the

152 Moho discontinuity. The imaged faults are spatially tied to ridge-parallel fault structures 
153 that represent pre-existing zones of weakness. Fault offsets gradually diminish up-section

154 with sediment age, suggesting growth faulting caused by repeated slip on basement

155 structures (Figs. 2 and 3). Our reflection image resolution permits identification of fault-

156 plane sections within the sediments with throws $>2-3 \mathrm{~m}$. This resolution estimate is

157 governed by the data sample rate $(2 \mathrm{~ms})$, sediment interval velocities $(1550-3300 \mathrm{~m} / \mathrm{s})$,

158 and frequency content of the signal (from $\sim 2 \mathrm{~Hz}$ to over $100 \mathrm{~Hz}$ ). Therefore, based only

159 on the reflection images, we cannot conclude whether the lack of visible faulting within

160 the topmost sediments (Fig. 3) is due to the limited image resolution, or due to the

161 absence of recent dip-slip displacement on these structures.

162 To resolve this, we first estimate the maximum longterm fault-throw rates for the 163 study area and then compare them with the recent sedimentation rates. Maximum fault 164 throws of $110 \pm 10 \mathrm{~m}$ are observed offshore Oregon, just west from the trench along the 165 ODP Leg 146 line 8. The shortest distance seaward from this fault toward the onset of 166 faulting is $200 \pm 20 \mathrm{~km}$, and the half spreading rate is $28 \mathrm{~mm} / \mathrm{yr}$ (e.g., Wilson, 1993). This 167 information yields a maximum longterm throw rate of $15 \pm 2 \mathrm{~mm} / \mathrm{kyr}$. We also estimate 168 the same parameters along the 2002 Juan de Fuca survey transect 17-3-1 offshore 169 Vancouver Island/Olympic Peninsula that spatially coincides with the Endeavour $170 \mathrm{ODP} / \mathrm{IODP}$ drilling transect, and for which there is a wealth of information about the 171 sedimentation rates. Maximum identified throw along this profile is $20 \pm 2 \mathrm{~m}$; trench 172 normal distance between the maximum throw fault and the seaward onset of faulting is $17350 \pm 5 \mathrm{~km}$; and the half spreading rate is also $28 \mathrm{~mm} / \mathrm{yr}$. These data yield a maximum 174 long-term throw rate of $11 \pm 2 \mathrm{~mm} / \mathrm{kyr}$. The two calculated long-term throw rates agree 175 within the error limits and combined give an average long-term throw rate for the imaged 176 normal faults along the Juan de Fuca plate of $13 \pm 2 \mathrm{~mm} / \mathrm{kyr}$. This long-term throw-rate 177 estimate is more than 25 times smaller than the rapid average sedimentation rate of $\sim 336$ $178 \mathrm{~mm} / \mathrm{kyr}$ obtained for the time-stratigraphic period A characterizing the past $90 \mathrm{kyr}$ along 
179 the Endeavour ODP/IODP drilling transect (Underwood et al., 2005). The topmost

180 sediments accumulated during the time-stratigraphic period A have an average thickness

181 of some $30 \mathrm{~m}$ while the estimated cumulative fault throw during this period is $1.17 \pm 0.18$

$182 \mathrm{~m}$, less than the resolution threshold for our images. This suggests that plate-deforming

183 processes have remained active during most recent geologic time with the resulting

184 normal faulting displacing the whole sediment column.

185 Fault throws show no reversals in slip direction and gradually increase both

186 downsection, from younger to older sediments, and toward the trench with increasing

187 crustal age. Observations of compaction-induced sediment folding without faulting at

188 places where there are large offsets in the basement structure (e.g., Fig. 3 at $\sim 125 \mathrm{~km}$;

189 Fig. 4 at $\sim 85 \mathrm{~km}$; Figs. 5 and 6 at $\sim 120 \mathrm{~km}$ ) suggests that the sediment rupture is not

190 caused by compaction, but rather by movement of basement fault systems. Particularly

191 supportive of this interpretation is the Fig. 4 reflection image of the section of transect

192 17-3-1 showing significant sediment accumulation on the western Endeavour ridge flank.

193 Folding of sedimentary strata due to differential compaction over the rough igneous

194 basement is present throughout the mini-basins but no faulting can be observed despite

195 the large, up to a few hundred meters high steps in the basement structure. These mini-

196 basins extend to more than $110 \mathrm{~km}$ west from the Endeavour ridge axis, significantly

197 farther than the distance east from the Juan de Fuca ridge axis $(55-110 \mathrm{~km})$ at which the

198 seaward limit of faulting is observed on all transects (Figs. 1, 2, 3, 6). Moreover,

199 sediment thickness in the mini-basins over the western Endeavour ridge flank (Fig. 4) is

200 twice that on the eastern Endeavour flank at the seaward limit of faulting (Fig. 2), further

201 indicating that the faulting is caused by movement of basement fault systems and not

202 differential compaction. However, faulting in the sediments where there are only small

203 offsets in the basement implies that faulting does not in all cases occur at the pre-existing

204 planes of weakness formed at the Juan de Fuca ridge system. 
The growth-fault interpretation is in general in agreement with the existing

206 lithospheric stress models for the Juan de Fuca plate system (Wang et al., 1997).

207 Nevertheless, the intraplate stress regime for the Juan de Fuca plate system is known to

208 be complex, with variable distribution of compressive and tensile stresses, and it is

209 possible that many of the described faults may have also experienced transcurrent

210 motion. Based on reflection images of the sediments (MacKay et al., 1992; Gulick et al.,

211 1998), and from earthquake studies and high-resolution images of the seafloor (Chaytor

212 et al., 2004), strike-slip and normal faulting have both been suggested for the Gorda and

213 southern part of the Juan de Fuca plate. Our images are 2D and sparsely distributed thus

214 providing no constraints on transcurrent motion along the imaged faults.

215 Crustal faulting within young oceanic plates is in most cases inferred from offsets

216 observed at the igneous basement or within the overlying sediments, as shown in Fig. 3.

217 Fig. 2 is exceptional because it shows reflections from the fault planes that can be

218 identified within the lower half of the image, or the lower two-thirds of the igneous

219 oceanic crust assuming average crustal velocities. The deep faulting projects to offsets in

220 the igneous basement and sediments indicating that the faults transect the whole crust.

221 This suggests that the imaged faults are listric - too steep to be imaged in the shallow-

222 most crust, and sloping gently enough to be imaged at greater depth.

223 Crustal reflections can potentially also be caused by varying mineralogical

224 content (e.g., of plagioclase) inherited from axial igneous processes; however, the

225 geometry of the boundary between crustal zones of different mineralogical content is

226 unlikely to both a) be identical to that caused by normal faulting and b) spatially correlate

227 with the position of basement scarps and faulting in the sediments. Furthermore, the

228 sharp changes in crustal mineralogical content needed to produce imageable reflections

229 are not common in nature, at least not in our study area where images of the oceanic crust 
230 are void of any reflectivity excluding the top of the igneous crust and Moho events, and

231 the small number of fault-related steeply dipping events discussed in this work.

232 The imaged fault reflections are not migration or other artefacts because their

233 geometrical shape does not resemble that of migration 'smiles', they extend over a very

234 long distance through the sections, and they project onto the displaced sediments.

235 Moreover, the seismic sections formed using data collected during the 2002 Juan de Fuca

236 cruise are of high signal-to-noise ratio (Nedimović et al., 2005) and are generally void of

237 seismic noise that could be misinterpreted as fault reflections. Primary multiples are very

238 strong and limit the depth to which the obtained images can be interpreted. In Fig. 2,

239 primary multiples arrive at about $7 \mathrm{~s}$ two-way traveltime. We show this section to $6.4 \mathrm{~s}$

240 two-way traveltime because the deeper portion to $7 \mathrm{~s}$ is affected by primary multiples

241 migration noise.

242 The observed fault reflections returning from within the mostly gabbroic oceanic

243 crust and mostly peridotitic uppermost mantle are possible only if the rocks along the

244 fault surfaces are altered to produce an acoustic impedance contrast. As these alteration

245 products require the availability of seawater, this indicates that the extensional faults

246 along the Juan de Fuca plate system are conduits for fluids and that their observed depth

247 extent in the reflection images should constrain the local depth limit of plate hydration.

248 The depth of imageable fault penetration correlates well with the $500-600{ }^{\circ} \mathrm{C}$ isotherm

249 and is approximately coincident with the location of the Moho reflection (Fig. 2). At

250 greater depths and therefore greater temperatures, serpentinization, the most important

251 hydration mechanism for peridotites, becomes a marginal process (Ulmer and

252 Trommsdorff, 1995). The lowest Juan de Fuca plate temperatures are expected along the

253 Oregon Margin (8-10 Ma crust); however, due to the increasing accumulation of an

254 insulating and heat producing sediment layer, thermal models predict that Moho

255 temperatures will remain high $\left(450-500^{\circ} \mathrm{C}\right)$ as the plate enters the trench (Hyndman and 
256 Wang, 1993, 1995; Wang et al., 1995). Therefore, it appears that prior to subduction only

257 the uppermost Juan de Fuca mantle can become hydrated by peridotite "corrosion" to

258 serpentinite, despite the pervasive extensional faulting imaged seaward of the trench

259 (Figs. 2 and 3).

260 After subduction, increased pressure may cause the antigorite stability region to

261 initially increase as the slab starts to descend (e.g., Wada et al., 2008). Provided fault

262 systems maintain permeability, free-water within the plate could facilitate additional and

263 deeper serpentinization of the mantle rocks during this time. This process is expected to

264 be common to all slabs; however, its extent cannot be assessed readily from reflection

265 imaging. Dehydration occurs during later stages of subduction in response to slab

266 warming.

\section{5. Comparisons and implications}

268 The only other convergent margin with both seismic reflection evidence for the

269 depth extent of faulting and thermal modelling results is the Middle America subduction

270 zone (Ranero et al., 2003; Harris and Wang, 2002). Normal faulting offshore Middle

271 America margin covers a narrower swath of seafloor $(\sim 60 \mathrm{~km})$ but is more pronounced

272 than offshore Cascadia margin where the faulted area is wider $(100-250 \mathrm{~km})$. The width

273 of the faulted area offshore Middle America appears consistent with the $40-75 \mathrm{~km}$ wide

274 area estimated from lower resolution single-channel seismic and sidescan images from

275 the outer-rise region of other subduction zones (e.g., Mason, 1991). The anomalously

276 wide zone documented on the Juan de Fuca plate may indicate that the stress field within

277 this small plate is not controlled solely by plate bending, but includes contributions from

278 thermal contraction and basal shear, as well as ridge and transform push (Wang, 1997).

279 Fault fabric inherited from crustal accretion at the ridge also has relatively little time to

280 heal and may therefore be reactivated even under small differential stresses found at a 
281 great distance from the trench. Alternatively, the faulting offshore Middle America

282 margin (and elsewhere) may start at a greater distance from the trench than observed, but

283 the combination of slower sedimentation rates and few available high quality MCS

284 reflection images makes it impossible to resolve faults with throws smaller than $\sim 10-20$

$285 \mathrm{~m}$ with the existing data.

286 Faults are imaged to depths of $\sim 6-7 \mathrm{~km}$ within the Juan de Fuca plate system.

287 Although there are currently no seismic reflection constraints on the depth extent of

288 faulting within the oldest portions of the plate near the Cascadia margin, thermal

289 modelling (Hyndman and Wang, 1993,1995; Wang et al., 1995) indicates that these

290 systems should extend no more than a few kilometers into slab mantle. At the Middle

291 America trench, however, faults are imaged to depths of $\sim 20-22 \mathrm{~km}$, some $15 \mathrm{~km}$ into the

292 upper mantle. Like at the Cascadia margin, the depth of imageable fault penetration at the

293 Middle America trench correlates well with the $500-600{ }^{\circ} \mathrm{C}$ isotherm from thermal

294 models. The Middle America outer-rise fault density gradually increases toward the

295 trench reaching $\sim 8$ faults per $5 \mathrm{~km}$. Fault density at the Cascadia margin, although

296 variable, is comparatively low across the faulted area with $\sim 1-2$ faults per $5 \mathrm{~km}$ trench-

297 normal distance. While fault throws at the Middle America trench can reach $\sim 500 \mathrm{~m}$,

298 those adjacent to the Cascadia trench exhibit maximum offsets of only $\sim 110 \mathrm{~m}$. These

299 differences in fault density, fault throws, and imageable depth of fault penetration suggest

300 that the amount of water bound in the subducting slab at the Middle America trench is

301 significantly greater than that at the Cascadia margin. Specifically, the contribution from

302 serpentinized upper mantle rocks, which is equivalent to a $0.17-1.7 \mathrm{~km}$-high column of

303 water per unit length at the Middle America trench (Ranero et al., 2003), appears to be

304 largely absent along Cascadia. This missing volume rivals the amount of water stored in

305 the igneous oceanic crust (Moore and Vrolijk, 1992). 
Much attention has been given to the role of dehydration embrittlement in

307 triggering intermediate-depth earthquakes within the subducting slab and the localization

308 of these seismic events on pre-existing fault sets (Raleigh and Patterson, 1965; Yamasaki

309 and Seno, 2003; Hacker et al., 2003b). As shown in Fig. 1, intraslab seismicity at the

310 Cascadia margin is sparse and shallow $(<\sim 80-90 \mathrm{~km})$, and focused in only a few areas-

311 the southern margin of the slab near the Mendocino triple junction, the eastern Olympic

312 peninsula region, and to a lesser extent the area beneath mid-western Vancouver Island

313 (Fig. 1). The largest recorded intraslab events occur in a small area offshore northern

314 California, have shallow hypocenters ( $<20 \mathrm{~km}$ depth $)$, strike-slip mechanisms, and

315 moment magnitudes of up to 7.3 (Wong, 2004). The largest intermediate-depth intraslab

316 earthquakes occur onshore across the northern Cascadia subduction zone. Their observed

317 maximum moment magnitudes are $\sim 6.8$ (April 23, 1949 Olympia and February 28, 2001

318 Nisqually earthquakes) (Malone, 2001; Rogers and Crosson, 2002). In the case of the

3192001 Nisqually earthquake (slab age $\sim 10 \mathrm{Ma}$ at the time of subduction), waveform

320 analysis suggests that the rupture occurred on a steeply dipping plane that spanned the

321 lower oceanic crust and extended no more than $10 \mathrm{~km}$ into the subducted mantle (Kao et

322 al., 2008). This is consistent with the idea that as antigorite dehydration begins and fluids

323 migrate upward, the maximum depth extent of the embrittled mantle region is limited by

324 the original depth of hydration. By comparison, the maximum moment magnitude for

325 analogous, intermediate-depth events recorded at the Middle America margin, which is

326 characterized by abundant and deeper reaching $(300 \mathrm{~km})$ intermediate depth seismicity, is

327 nearly a full magnitude unit larger (Seno and Yoshida, 2004). For the largest recorded

328 event, the January 13, 2001 El Salvador earthquake $\left(M_{w} 7.7\right)$, significant moment release

329 is observed along a steeply $\left(60^{\circ}\right)$ dipping plane with a down-dip dimension of roughly 25

$330 \mathrm{~km}$, extending well into the subducted upper mantle (Vallée et al., 2003). 
The maximum depth of intraslab seismicity is well known to correlate with slab

332 thermal parameter, the product of slab age and subduction rate (Kirby et al., 1996). This

333 is commonly interpreted to reflect the temperature-dependant locus of dehydration within

334 metamorphosed oceanic crust and serpentinized slab mantle (Raleigh and Paterson, 1965;

335 Peacock, 2001; Hacker et al., 2003a,b). However, MCS observations also show that the

336 dense and deep-cutting faulting of the older (14-24 Ma), colder and thicker (50-55 km)

337 downgoing Cocos plate at the Middle America trench provides a mechanism to embed

338 into the oceanic plate a volume of water much greater than that for the young (4-10 Ma),

339 warm and thin (30-35 km) Juan de Fuca plate. This enhanced availability of water may

340 create an environment more prone to brittle failure once the dehydration processes start.

341 Moreover, water bound within the Cascadia slab is mostly contained within the hydrous

342 crustal mineral phases, rather than serpentinized mantle peridotite, which remains stable

343 at higher temperatures (greater depths) within the slab (Yamasaki and Seno, 2003;

344 Hacker et al., 2003b). Deep fault penetration into the Cocos plate at the Middle America

345 trench also creates pre-existing zones of weakness with larger surface area relative to

346 those at the Cascadia margin, leading to higher potential for larger magnitude intraslab

347 earthquakes.

348 In addition to the low frequency of intraslab earthquakes beneath Cascadia,

349 relative to Middle America, we note that the sparse seismicity of the slab is clustered

350 tightly within the northern and southern portions of the plate (Fig. 1). The uniform

351 thickness and structure of Juan de Fuca crust formed along the spreading center

352 (Nedimović, et al., 2005) suggests that these clusters may be caused by anomalous

353 hydration of the lithospheric plate as it ages and/or by larger intraslab differential

354 stresses. In this regard, the northward migration of the Mendocino Triple Junction and the

355 accompanying retreat of the slab (Furlong and Schwartz, 2004) may create anomalous

356 stress conditions along the southern margin of the plate. The Mendocino transform zone 
357 also may be cooled more rapidly than the rest of the plate due to a thermal boundary

358 effect (e.g., Louden and Forsyth, 1976) caused by juxtaposition of the old and cold

359 Pacific plate and the young and warm Gorda plate, allowing deeper and more extensive

360 hydration along this long-lived fault zone. Further facilitating hydration of the oceanic

361 plate in this area are two sets of crossing faults observed in reflection profiles (Gulick et

362 al., 2001). The internally deforming and fragmenting southern Gorda plate is rotating

363 clockwise toward the Mendocino triple junction. This causes the incoming ridge fabric to

364 be oriented at a high angle to the trench (Fig. 1). When the strike of the incoming oceanic

365 spreading fabric forms an oblique angle $\left(>20-30^{\circ}\right)$ with the trench, a new set of trench-

366 parallel faults is formed (Masson, 1991) providing fluid pathways into the oceanic plate

367 in addition to those formed at the spreading center and reactivated near the trench.

368 In the north, intraslab stresses are influenced by interactions with the Nootka

369 transform fault, which plunges beneath mid-western Vancouver Island (Fig. 1), and by

370 the sharp along-strike bending of the slab beneath Olympic Peninsula. The trench bends

371 westward in this area and, like at the southern Gorda plate, becomes oblique to the ridge

372 tectonic fabric. Therefore, it is possible that two-directional faulting and associated

373 enhanced plate hydration also take place in this northern locality but without new MCS

374 data this cannot be validated.

\section{6. Effect of propagator wakes}

376 We also investigate the spatial relationship between the location of propagator

377 wakes and the distribution of seismicity within both the Juan de Fuca plate system and

378 the subducted oceanic slab at the Cascadia margin. While the smaller Explorer and

379 Gorda plates show evidence of seismicity, and presumably active faulting, throughout

380 much of their interior [e.g., Fox and Dziak, 1999; Dziak, 2006], earthquakes located

381 within the Juan de Fuca plate are concentrated along a broad NE-trending propagator 
382 wake crossing the eastern Cleft ridge flank (Fig. 1). This region includes a swarm of

$383>600$ SOSUS-detected events recorded in April 2008, positioned near $44^{\circ} \mathrm{N} / 128^{\circ} \mathrm{W}$ (Figs.

3841 and 5). The affected area is located near the eastern end of our seismic transect 87-89-

$38573-89 \mathrm{a}$. Analysis of the seismic reflection image formed along this $300 \mathrm{~km}$-long transect

386 shows that the only observable faulting in this profile spans the area crossing this

387 propagator wake (Fig. 6). These observations suggest that propagator wakes, as potential

388 zones of plate weakness inherited from crustal accretion, may respond to increasing

389 external stresses by brittle failure earlier and to a greater extent than other parts of

390 oceanic plates. Therefore, the identified faulting and associated earthquake activity

391 indicate that propagator wakes also may be areas of more pervasive plate hydration. As

392 such, these structures should after subduction correlate with zones of elevated intraslab

393 seismicity, assuming that dehydration embrittlement is an important mechanism for

394 triggering intermediate-depth earthquakes within the subducting slab.

395 Analysis of Fig. 1, however, shows that at the Cascadia margin there does not 396 appear to be a regional correlation between the inferred location of propagator wakes

397 within the subducted oceanic slab and the location of anomalous intraslab seismicity.

398 Despite the increased faulting of the Juan de Fuca plate along the propagator wakes, high

399 temperatures within this young and sedimented oceanic plate may generally limit

400 hydration of even the uppermost mantle such that additional hydration of the propagator 401 areas is limited in volume.

402 Locally, on the other hand, the propagator wake inferred beneath Olympic

403 Peninsula does appear to spatially correlate with the largest concentration of intraslab

404 seismicity at the northern Cascadia margin. Magnetic isochrons (Fig. 1) suggest that the

405 oceanic plate in this area may be older than in any other section of the subducted Juan de

406 Fuca plate system found at about the same distance from the trench. Taking into account

407 the N-S variability in the recent Cascadia margin convergence rates (e.g., $29 \mathrm{~mm} / \mathrm{yr}$ at the 
408 Oregon-Washington border, $40 \mathrm{~mm} / \mathrm{yr}$ at the Juan de Fuca Strait; Wells et al., 2002), this

409 section of the subducted plate exhibiting intraslab seismicity was likely the oldest and

410 therefore the coldest when it was at the trench. This, combined with additional fluid

411 pathways within the propagator wake area, likely facilitated deeper and more extensive

412 mantle hydration than elsewhere in the subduction zone and may contribute to the locally

413 elevated intraslab seismicity rate.

\section{7. Summary}

415 MCS data from EW0207 cruise provide the first direct imagery showing crustal

416 scale faulting within the Juan de Fuca plate. Steeply dipping faults within the sedimentary

417 layering are identified by stratigraphic offsets, with dip slip motion decreasing upsection.

418 Imaged faults are generally spatially tied to larger offset scarps in the basement

419 topography, suggesting reactivation of the normal fault systems formed at the spreading

420 center. The analysis of EW0207 data, combined with reflection images within the area

421 from earlier data, was used to map the extent of the Juan de Fuca plate region affected by

422 normal faulting. The mapped region of recent faulting appears to extend to distances of

$423>200 \mathrm{~km}$ from the trench.

424 Imaged reflections within the gabbroic igneous crust indicate swallowing fault

425 dips at depth. These reflections require local alteration to produce an impedance contrast,

426 suggesting that these structures provide pathways for fluid transport and hydration. As

427 the depth extent of imaged faulting within this young and sediment insulated oceanic

428 plate is primarily limited to approximately Moho depths (temperatures reach 500-600

$429{ }^{\circ} \mathrm{C}$ ), fault-controlled hydration is for the most part restricted to crustal levels. Hydration

430 of a thin layer of the uppermost mantle is most likely for sections along the trench where

431 the coldest and anomalously faulted parts of the Juan de Fuca plate system are subducted.

432 If dehydration embrittlement is an important mechanism for triggering intermediate- 
433 depth earthquakes within the subducting slab, then the limited occurrence rate and 434 magnitude of intraslab seismicity at the Cascadia margin may in part be explained by the 435 limited amount of water imbedded into the uppermost oceanic mantle prior to subduction. 436 The distribution of earthquakes within the Juan de Fuca plate system, including the 4372008 earthquake swarm, indicates that propagator wake area is likely to be more heavily 438 faulted and therefore more hydrated than other parts of oceanic plates. However, being 439 mostly restricted to the crust, this additional hydration does not appear to have an effect 440 on the distribution and magnitude of the intraslab seismicity at the Cascadia margin 441 except, perhaps, for the anomalous area below the Olympic Peninsula. 


\section{Acknowledgements}

443 This work was made possible through the generosity of American (T. M. Brocher, 444 J. B. Diebold, A. M. Trehu), Canadian (K. Vasudevan) and German (E. Flueh, D. 445 Klaeschen) researchers who provided seismic reflection data. D. S. Wilson kindly 446 supplied magnetic isochron information and critically reviewed the manuscript. We are

447 grateful to M. Protti, L. R. Sykes and G. A. Abers for comments on earlier drafts of this 448 work, which was supported by the Doherty Foundation and the National Science 449 Foundation under grants OCE002488 and OCE0648303 to SMC and MRN. 


\section{References}

Brocher, T.M., Davis, M.J., Clarke, S.H., Geist, E.L., 1995. Onshore-offshore wideangle seismic recordings in October 1994 near Cape Blanco, Oregon. U.S. Geological Survey Open-File Report 95-819, 69 p.

Calvert, A.J., Clowes, R.M., 1991. Seismic evidence for the migration of fluids within the accretionary complex of western Canada. Can. J. Earth Sci. 28, 542-556.

Calvert, A.J., 1996. Seismic reflection constraints on imbrication and underplating of the northern Cascadia convergent margin. Can. J. Earth Sci. 33, 1294-1307.

Chaytor, J.D., Goldfinger, C., Dziak, R.P., Fox, C.G., 2004. Active deformation of the Gorda "Plate": Constraining deformation models with new geophysical data. Geology 32, 353-356.

Davis, E.E., Karsten, J.L., 1986. On the cause of the asymmetric distribution of seamounts about the Juan de Fuca Ridge; ridge-crest migration over a heterogeneous asthenosphere. Earth Planet. Sci. Lett. 79, 385-396.

Dziak, R.P., 2006, Explorer deformation zone: Evidence of a large shear zone and reorganization of the Pacific-Juan de Fuca-North American triple junction, Geology, 34, 312-316.

Flueh, E.R., Fisher, M.A., Bialas, J., Childs, J.R., Klaeschen, D., Kukowski, N., Parsons, T., Scholl, D.W., ten Brink, U., Trehu, A.M., Vidal, N., 1998. New seismic images of the Cascadia subduction zone from cruise SO108 - ORWELL. Tectonophysics 293, 69-84.

Fox, C.G., Dziak, R.P., Matsumoto, H., Schreiner, A.E., 1994. Potential for monitoring low- level seismicity on the Juan de Fuca Ridge using fixed hydrophone arrays. Mar. Tech. Soc. J. 27, 22-30.

Fox, C. G., and R. P. Dziak, 1999. Internal deformation of the Gorda Plate observed by hydroacoustic monitoring. J. Geophys. Res. 104, 17603-17616. 
476 Furlong, K. P., S. Y. Schwartz, 2004. Influence of the Mendocino triple junction on the

477

478

479

480

481

482

483

484

485

486

487

488

489

490

491

492

494

495

496

497

498

499

500

501

502

503 tectonics of coastal California. Annual Review of Earth and Planetary Sciences, 32, 403-433.

Gulick, S.P.S., Meltzer, A.S., Clarke, S.H. Jr., 1998. Seismic structure of the southern Cascadia subduction zone and accretionary prism north of the Mendocino triple junction. J. Geophys. Res. 103, 27207- 27222.

Gulick, S. P. S., Meltzer, A. S., Henstock, T. J., Levander, A., 2001. Internal deformation of the southern Gorda plate: Fragmentation of a weak plate near the Mendocino triple junction, Geology, 29, 691-694.

Hacker, B.R., Abers, G.A., Peacock, S.M., 2003a. Subduction factory: 1. Theoretical mineralogy, densities, seismic wave speeds, and $\mathrm{H}_{2} \mathrm{O}$ content. J. Geophys. Res. 108, B12029, doi:10.1029/2001JB001127.

Hacker, B. R., S. M. Peacock, G. A. Abers, and S. D. Holloway, 2003b. Subduction factory: 2. Are intermediate-depth earthquakes in subducting slabs linked to metamorphic dehydration reactions? J. Geophys. Res. 108, B12030, doi:10.1029/2001JB001129.

Harris, R.N., Wang, K., 2002. Thermal models of the Middle America Trench at the Nicoya Peninsula, Costa Rica. Geophys. Res. Lett. 29, 21-24.

Hyndman R.D., Wang, K., 1993. Thermal constraints on the zone of major thrust earthquake failure: The Cascadia subduction zone. J. Geophys. Res. 98, 2039-2060.

Hyndman, R.D., Wang, K., 1995. The rupture of Cascadia great earthquakes from current deformation and thermal regime. J. Geophys. Res. 100, 22133-22154.

Jung, H., Green, H.W.II, Dobrzhinetskaya, L.F., 2004. Intermediate-depth earthquake faulting by dehydration embrittlement with negative volume change. Nature 428 , 545-549.

Kao, H., Wang., K., Chen, R.Y., Wada, I., He, J., Malone, S.D., 2008. Identifying the rupture plane of the 2001 Nisqually, Washington, Earthquake. Bull. Seis. Soc. Am. 98, doi:10.1785/0120070160, 1546-1558. 
504 Kirby, S., Engdahl, R.E., Denlinger, R., 1996. Intermediate-depth intraslab earthquakes

505

506

507

508

509

510

511

512

513

514

515

516 and arc volcanism as physical expressions of crustal and uppermost mantle metamorphism in subducting slabs, in: Bebout, G.E., Scholl, D., Kirby, S., Platt, J.P. (Eds.), Subduction: Top to Bottom. Geophysical Monograph 96, American Geophysical Union, Washington DC, pp. 195-214.

Kodaira, S., Iidaka, T., Kato, A., Park, J.-O., Iwasaki, T., Kaneda, Y., 2004. High pore fluid pressure may cause silent slip in the Nankai Trough. Science 304, 1295-1298.

Louden, K.E., Forsyth, D.W., 1976. Thermal conduction across fracture zones and the gravitational edge effect. J. Geophys. Res. 81, 4869-4874.

MacKay, M.E., Moore, G.F., Cochrane, G.R., Moore, J.C., Kulm, L.D., 1992. Landward vergence and oblique structural trends in the Oregon margin accretionary prism: Implications and effect on fluid flow. Earth Planet Sci. Lett. 109, 477-491.

Malone, S., 2001. Preliminary report on the $\mathrm{Mw}=6.8$ Nisqually, Washington, earthquake of 28 February 2001. Seism. Res. Lett. 72, 352-361.

Masson, D.G., 1991. Fault patterns at outer trench walls. Mar. Geophys. Res. 13, 209225.

McCrory, P.A., Blair, J.L., Oppenheimer, D.H., Walter, S.R., 2004. Depth to the Juan De Fuca Slab Beneath the Cascadia Subduction Margin - A 3-D Model for Sorting Earthquakes. U.S. Geological Survey Data Series 91, version 1.0.

Meade, C., Jeanloz, R., 1991. Deep-focus earthquakes and recycling of the water into the earth's mantle. Science 252, 68-72.

Moore, J.C., Vrolijk, P., 1992. Fluids in accretionary prisms. Rev. Geophys. 30, 113-135.

Nedimović, M.R., Hyndman, R.D., Ramachandran, K., Spence, G.D., 2003a. Reflection signature of seismic and aseismic slip on the northern Cascadia subduction interface. Nature 424, 416-420.

Nedimović, M.R., Mazzotti, S., Hyndman, R.D., 2003b. Three-dimensional structure from feathered two-dimensional seismic reflection data; The eastern Nankai trough. J. Geophys. Res. 108, B10, 2456, doi:10.1029/2002JB001959, 1-14. 
532 Nedimović, M.R., Carbotte, S.M., Harding, A.J., Detrick, R.S., Canales, J.P., Diebold, 533 J.B., Kent, G.M., Tischer, M., Babcock, J.M., 2005. Frozen magma lenses below the 534 oceanic crust. Nature 436, 1149-1152.

535 Nedimović, M. R., Carbotte, S. M., Diebold, J. B., Harding, A. J., Canales, J. P., Kent, G. 536 M., 2008. Upper crustal evolution across the Juan de Fuca ridge flanks. Geochem. 537 Geophys. Geosyst., 9, Q09006, doi:10.1029/2008GC002085, 1-23.

538 Oleskevich, D.A., 1996. Thermal constraints on great earthquake rupture zones [M.Sc. 539 Thesis]: University of Victoria, $170 \mathrm{p}$.

540 Peacock, S.M., 1990. Fluid Processes in Subduction Zones. Science 248, 329-337.

541 Peacock, S.M., 2001. Are the lower planes of double seismic zones caused by serpentine 542 dehydration in subducting oceanic mantle? Geology 29, 299-302.

543 Raleigh, C.B., Paterson, M.S., 1965. Experimental deformation of serpentinite and its 544 tectonic implications. J. Geophys. Res. 70, 3965-3985.

545 Ranero, C. R., Phipps Morgan, J., McIntosh, K., Reichert, C.B., 2003. Bending-related 546 faulting and the mantle serpentinization at the Middle America trench. Nature 425, $547 \quad 367-373$.

548 Rogers, G.C., Crosson, R.S., 2002. Intraslab earthquakes beneath Georgia Strait/Puget Sound, in: Kirby, S., Wang, K., Dunlop, S., (Eds.), The Cascadia Subduction Zone and Related Subduction Systems. U.S. Geological Survey Open-File Report 02-328

552 Seno, T., Yoshida, M., 2004. Where and why do large shallow intraslab earthquakes 553 occur? Physics of Earth and Planetary Interiors 141, 183-206.

554 Shipley, T.H., Moore, G.F., Bangs, N.L., Moore, J.C., Stoffa, P.L., 1994. Seismically 555 inferred dilatancy distribution, northern Barbados Ridge decollement: Implications 556 for fluid migration and fault strength. Geology 22, 411-414.

557 Tatsumi, Y., Eggins, S., 1995. Subduction zone magmatism, Oxford, Blackwell Science. 558 Ulmer, P., Trommsdorff, V., 1995. Serpentine stability to mantle depths and subduction559 related magmatism. Science 268, 858-861. 
560 Underwood, M.B., Hoke, K.D., Fisher, A.T., Davis, E.E., Giambalvo, E., Zühlsdorff, L., Spinelli, G.A., 2005. Provenance, stratigraphic architecture, and hydrogeologic influence of turbidites on the mid-ocean ridge flank of northwestern Cascadia Basin, Pacific Ocean. J. Sediment. Res. 75, 149-164.

Vallée, M., M. Bouchon, S.Y. Schwartz, 2003, The 13 January 2001 El Salvador earthquake: A multidata analysis, J. Geophys. Res., 108, 2203, doi:10.1029/2002JB001922.

Wada, I., Wang, K., He., J., Hyndman, R.D., 2008. Weakening of the subduction interface and its effects on surface heat flow, slab dehydration, and mantle wedge serpentinization. J. Geophys. Res. 113, B04402, doi:10.1029/2007JB005190.

Wang, K., He, J., Davis, E.E., 1997. Transform push, oblique subduction resistance, and

Wang, K., Mulder, T., Rogers, G.C., Hyndman, R.D., 1995. Case for very low coupling stress on the Cascadia subduction fault. J. Geophys. Res. 100, 12907-12918.

Wells, R.E., Blakely, R.J., Weaver, C.S., 2002. Cascadia microplate models and withinintraplate stress of the Juan de Fuca plate. J. Geophys. Res. 102, 661-674.

Wang, K., Cassidy, J.F., Wada, I. Smith, A.J., 2004. Effects of metamorphic crustal densification on earthquake size in warm slabs. Geophys. Res. Lett. 31, L01605, doi:10.1029/2003GL018644.

Wilson, D.S., 1988. Tectonic history of the Juan de Fuca ridge over the last 40 million

Wilson, D.S., 1993. Confidence intervals for motion and deformation of the Juan de Fuca years. J. Geophys. Res. 93, 11863-11876.

585 Wilson, D.S., 2002. The Juan de Fuca plate and slab-Isochron structure and Cenozoic 586 plate motions, in: Kirby, S., Wang, K., Dunlop, S., (Eds.), The Cascadia Subduction 587 Zone and Related Subduction Systems. U.S. Geol. Survey Open-File Report 02-328 and Geological Survey of Canada Open-File 4350, pp. 9-12. 
589 Wong, I.G., 2004. Low potential for large intraslab earthquakes in the central Cascadia

590 subduction zone: Bull. Seis. Soc. Am., 95, 1880-1902.

591 Yamasaki, T., and T. Seno, 2003. Double seismic zone and dehydration embrittlement of

592 the subducting slab. J. Geophys. Res. 108, B42212, doi:10.1029/2002JB001918.

593 


\section{Figure captions}

594 Fig. 1. Juan de Fuca plate regional seismicity and crustal age superimposed over

595 grayscale bathymetry. Crustal scale marine MCS profiles from eight regional surveys are

596 shown using thick brown lines. Line numbers are defined as in original surveys. White

597 sections on transects 17-3-1, 34-32 and 87-89-73-89a represent the locations of the

598 images shown in Figs. 2, 3, 4 and 6 respectively. Dashed white rectangle outlines the area

599 shown in Fig. 5. Thick dashed orange line shows the location of the thermal profile of

600 Wang et al. (1995) crossing the northern Cascadia margin. Thick black line on the

601 subducting plates outlines the seaward limit of the region of extension or transtension

602 where normal faulting is observed (solid) or inferred (dashed). Doted black line shows

603 the location of the trench. Long N-trending black isodepth lines (McCrory et al., 2004)

604 show the position of the Juan de Fuca oceanic slab beneath North America. Red dots are

605 earthquakes recorded from 1991 to 2004 by the Sound Surveillance System (SOSUS)

606 (Fox et al., 1994; http:/www.pmel.noaa.gov/vents/acoustics/autochart/GetPosit.html).

607 Blue dots are intraslab earthquakes with magnitudes $>2$ recorded from 1975 to 2002 and

608 extracted from the Advanced National Seismic System catalog (McCrory et al., 2004).

609 Green dots near the eastern end of transect 87-89-73-89a represent the SOSUS-detected

610 earthquake swarm from April 2008. White lines with black edges are the interpreted

611 traces of the ridge axis; dashed over fracture zones. Thin pink lines are magnetic

612 isochrons that outline color shaded magnetic anomalies 1 through $5 \mathrm{C}$, and grey shading

613 outlines propagator wakes (Wilson, 1988; 2002). JDF - Juan de Fuca plate; EX -

614 Explorer plate; GA - Gorda deformation zone; RDFZ - Revere-Dellwood fracture zone;

615 SFZ - Sovanco fracture zone; NF - Nootka fault; BFZ - Blanco fracture zone; MFZ -

616 Mendocino fracture zone. Inset in the upper right corner shows the location of the study

617 area with respect to North America. 
618 Fig. 2. Seismic reflection image of normal faults rooted near the Moho discontinuity and 619 extending through the crust and the overlying sediments is extracted from transect 17-3-1

620 (see Fig. 1 for location). Such direct imaging of normal faulting in young oceanic plates

621 from seafloor to Moho is not common because normal-fault planes dip steeply and

622 generally appear transparent for the seismic reflection method. Temperatures on the right 623 side are derived from a half-space cooling model for 2.75 Ma-old oceanic crust assuming 624 thermal diffusivity $\kappa=0.804 \times 10^{-6} \mathrm{~m}^{2} / \mathrm{s}$ and initial temperature $\mathrm{T}_{\mathrm{m}}=1300^{\circ} \mathrm{C}$. To simulate

625 the impact of sedimentation, the temperature at the sediment-basement interface is

626 constrained as $\mathrm{T}_{\mathrm{s}}=25^{\circ} \mathrm{C}$, which assumes an average sediment thickness of $250 \mathrm{~m}$ as plate

627 ages and a $0.1^{\circ} \mathrm{C} / \mathrm{m}$ thermal gradient in the sediments. Advanced $1 \mathrm{D}$ and $2 \mathrm{D}$ finite-

628 element models of Juan de Fuca plate temperatures for areas closer to the trench and

629 within the subduction zone can be found in Wang et al. (1995) and Hyndman and Wang $630(1993,1995)$.

631 Fig. 3. Seismic reflection images showing normal faulting within the sediments at the 632 eastern end of transect 34-32. Also visible in the sections are the igneous basement 633 reflection and the layer $2 \mathrm{~A} / 2 \mathrm{~B}$ event that is believed to mark the location of the upper 634 crustal interface between the extrusives and sheeted dikes. (a) An $80 \mathrm{~km}$-long section of 635 transect 34-32 (see Fig. 1 for location) depicting the gradual westward transition from 636 faulted to not faulted sediments. The white dashed box in (a) outlines the location of the 637 detailed image of faulting shown in depth in (b). Conversion from twtt to depth was done 638 along vertical rays using interval velocities. The discontinuity marked by a vertical white 639 line in (b) at the distance of $\sim 129 \mathrm{~km}$ is at the location where lines 34 and 32 were 640 merged.

641 Fig. 4. Reflection image of the section of transect 17-3-1 showing significant sediment 642 accumulation confined to mini-basins found on the western Endeavour ridge flank. 
643 Folding of sedimentary strata due to differential compaction over the rough igneous

644 basement is present throughout the mini-basins, but no faulting can be observed although

645 the steps in the basement reach up to a few hundred meters.

646 Fig. 5. Earthquake swarm of 2008 (red dots) superimposed over crustal age and grayscale

647 bathymetry of the Cleft ridge segment (see Fig. 1 for location). Orange solid line is MCS

648 transect 87-89-73-89a from the EW0207 cruise. Reflection image of the transect section

649 underlined with a thick solid white line is shown in Fig. 6.

650 Fig. 6. Seismic reflection image showing the approximate location of the landward onset 651 of faulting at the eastern end of transect 87-89-73-89a (see Figs. 1 and 5 for location).

652 The earthquake swarm shown in Fig. 5 partially overlaps the faulted section and extends 653 further east. 


\section{Table captions}

655 Table. 1. Summary information characterizing seismic reflection data from all crustal

656 scale MCS surveys with streamers $2.4 \mathrm{~km}$ or longer across the Juan de Fuca plate system. 
Nedimovic et al., Fig. 1

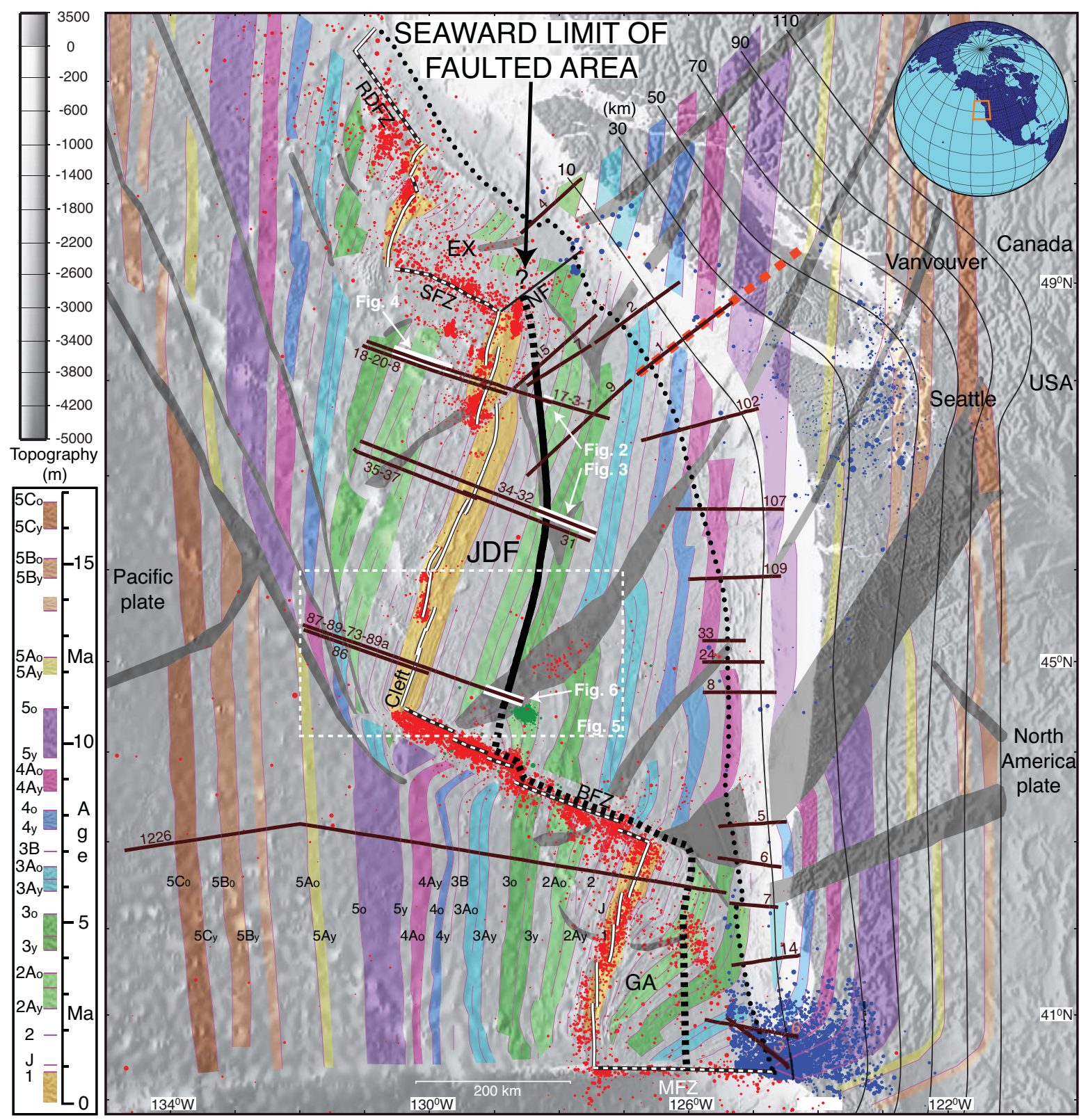


Nedimovic et al., Fig. 2

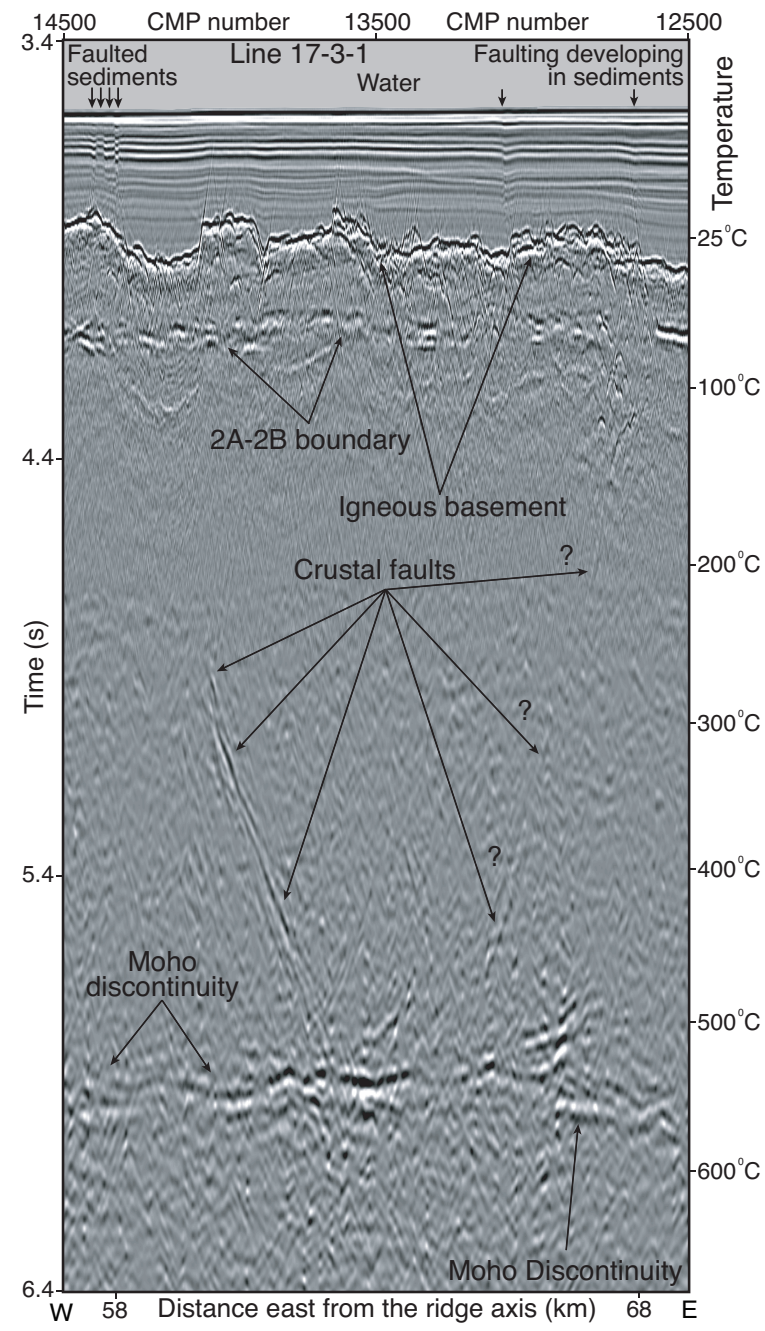


Nedimovic et al., Fig. 3

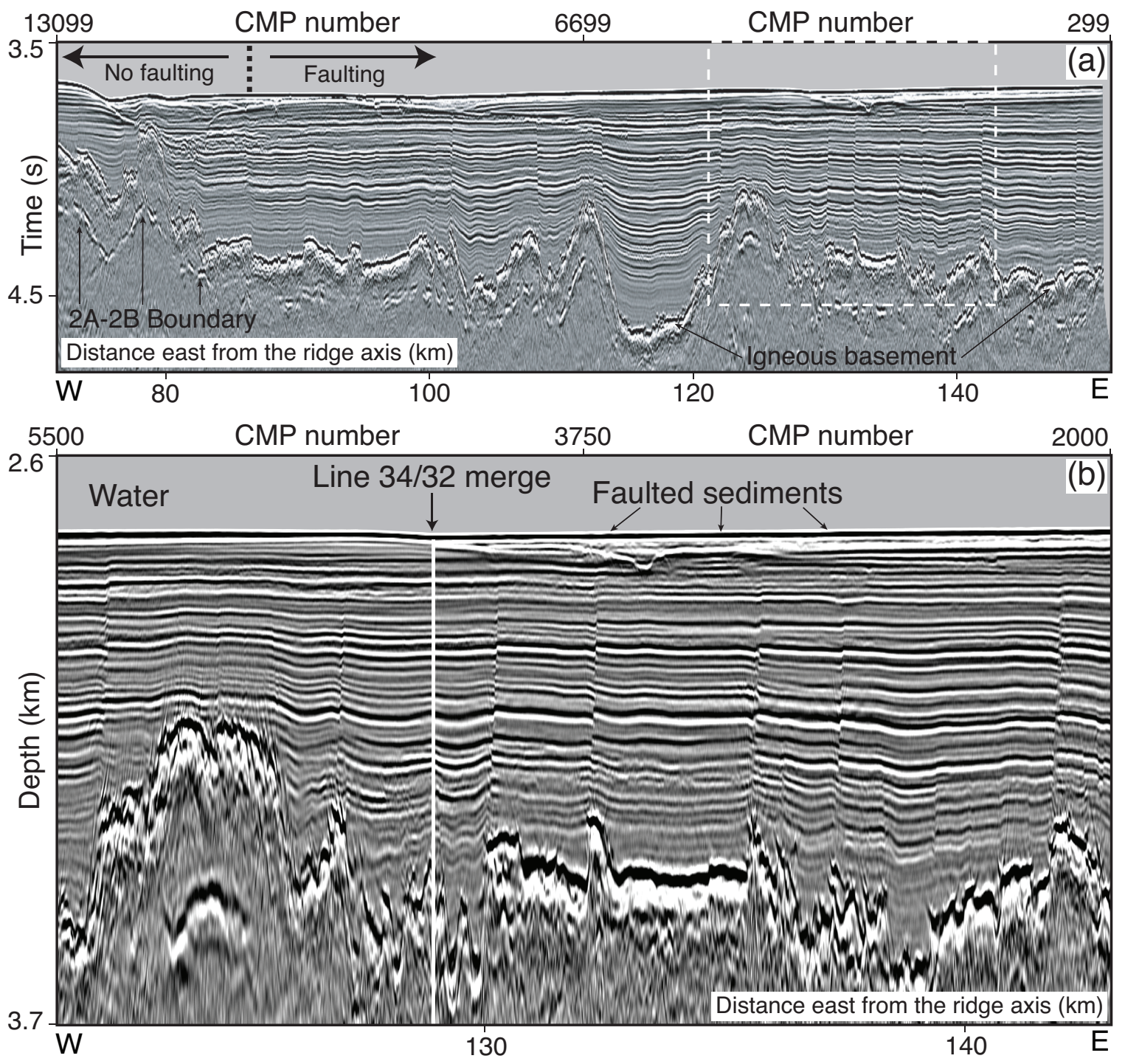


Nedimovic et al., Fig. 4

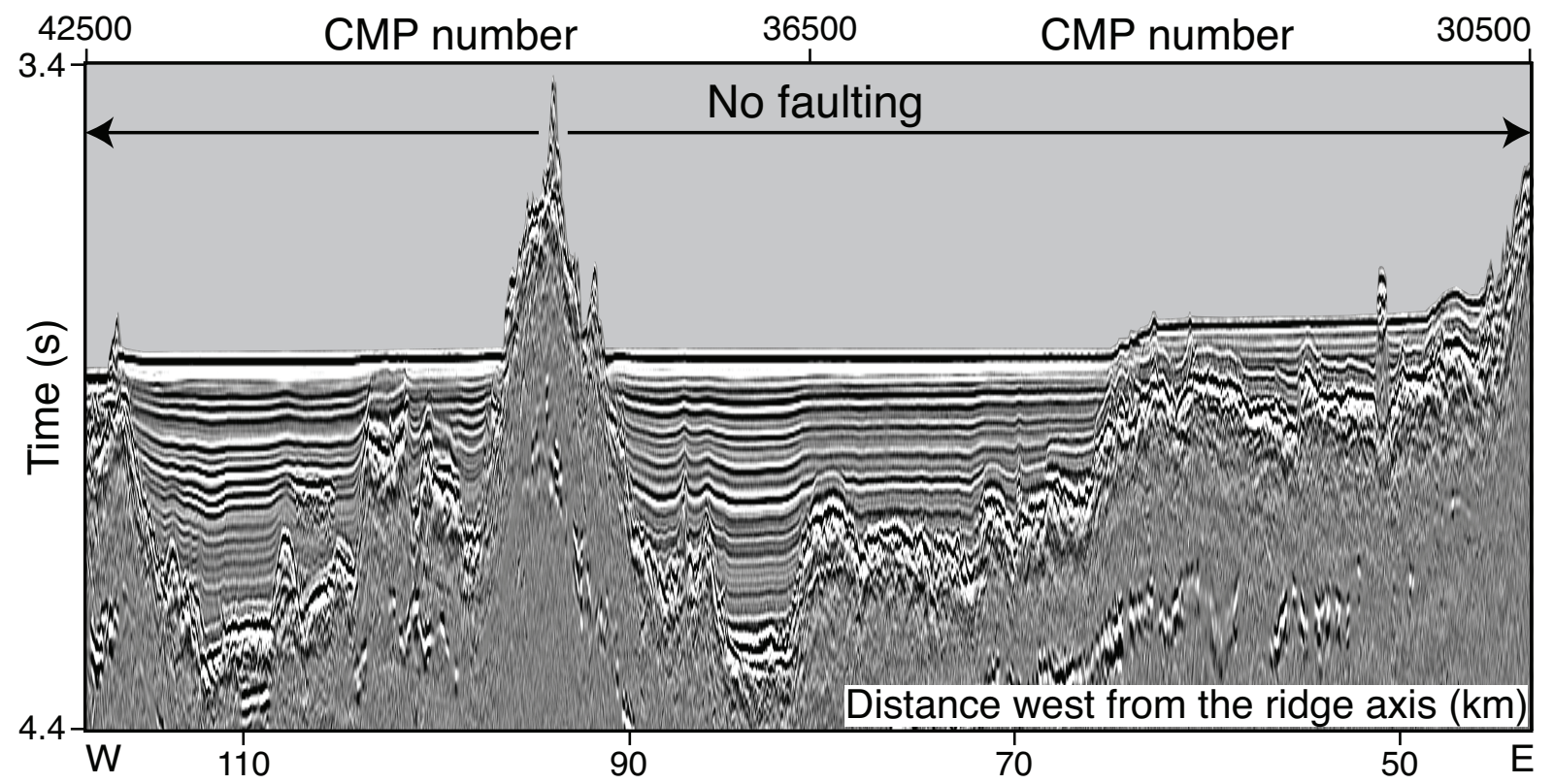


Nedimovic et al., Fig. 5

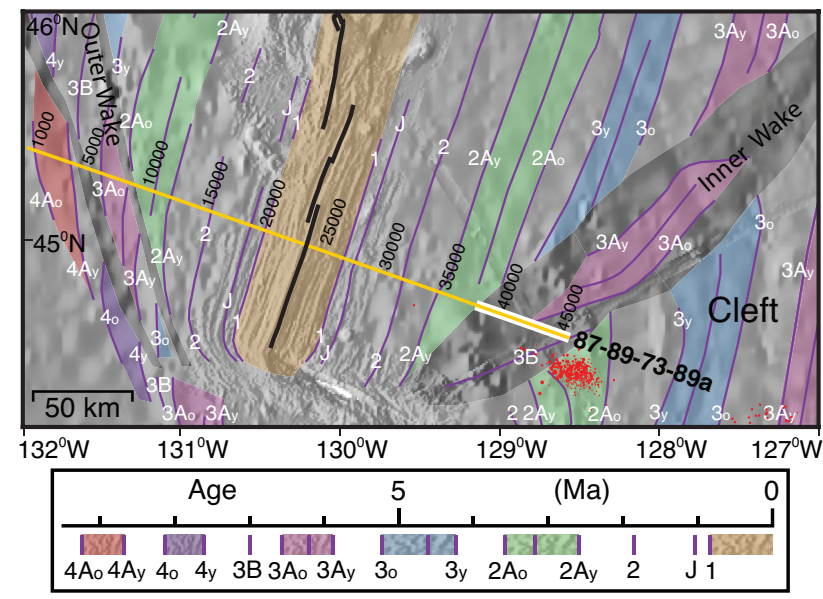


Nedimovic et al., Fig. 6

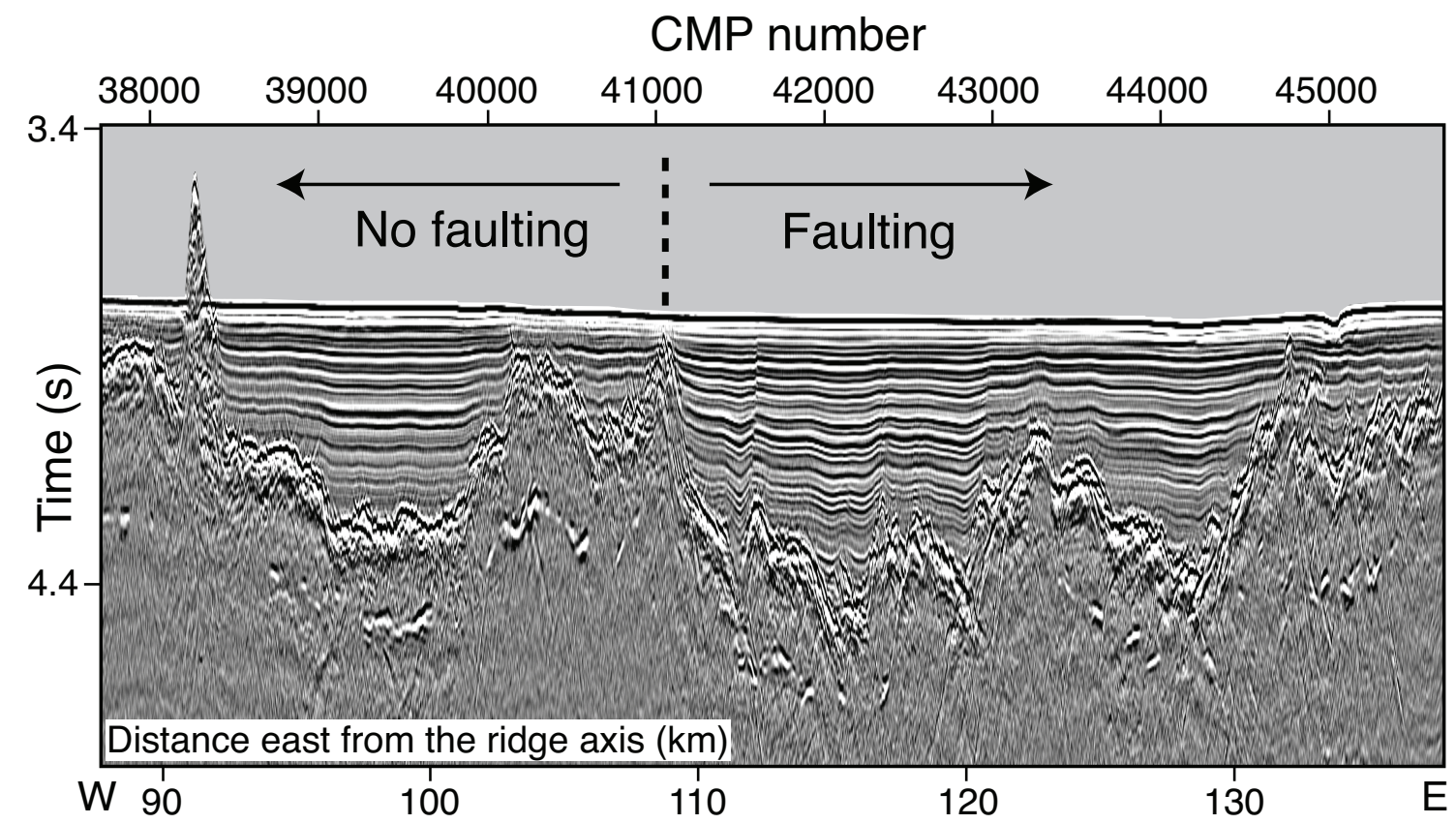


Nedimovic et al., Table 1

\begin{tabular}{|c|c|c|c|c|c|c|c|c|c|}
\hline 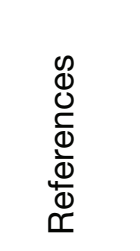 & 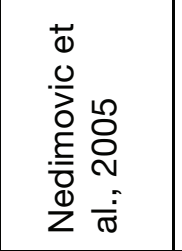 & 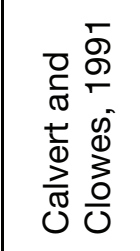 & $\begin{array}{l}\mathscr{9} \\
\stackrel{\circ}{+} \\
\frac{t}{0} \\
\frac{D}{\pi} \\
0\end{array}$ & 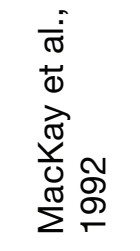 & 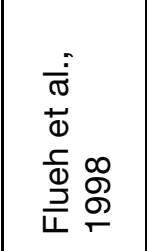 & $\begin{array}{ll}\frac{0}{0} & \\
3 & \\
0 & 0 \\
& \mathbb{D} \\
& \mathbb{0} \\
* & 0\end{array}$ & 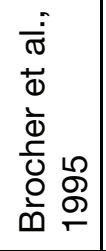 & 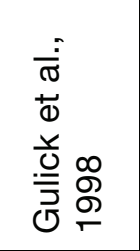 & 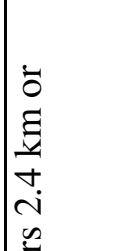 \\
\hline 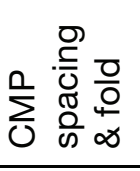 & $\begin{array}{l}\varepsilon \\
\text { Ln } \\
\sim \\
0\end{array}$ & 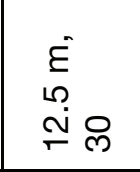 & 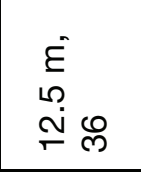 & $\begin{array}{l}\varepsilon \\
E \\
\stackrel{N}{N} N \\
\end{array}$ & $\begin{array}{l}\stackrel{\sim}{N} \\
\varepsilon \\
\stackrel{\sim}{N}\end{array}$ & 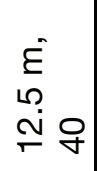 & $\begin{array}{l}\varepsilon \\
\underline{L} \\
\stackrel{\sim}{N} \\
\end{array}$ & $\begin{array}{l}\varepsilon \\
\dot{D} \\
\stackrel{1}{N} \text { 우 }\end{array}$ & 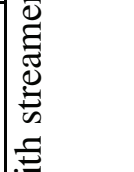 \\
\hline 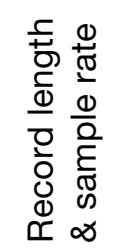 & 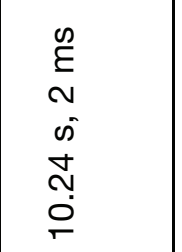 & 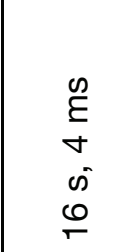 & $\begin{array}{l}\mathscr{\omega} \\
\varepsilon \\
\nabla \\
\omega \\
0 \\
0\end{array}$ & $\begin{array}{l}\mathscr{\infty} \\
\varepsilon \\
\dot{\sigma} \\
\infty \\
\infty\end{array}$ & 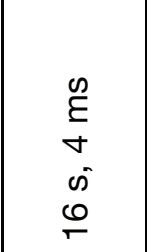 & 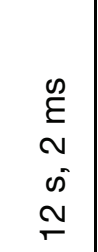 & 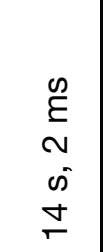 & 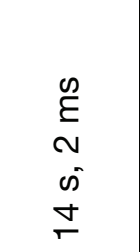 & 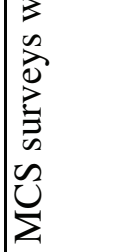 \\
\hline 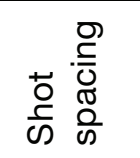 & $\begin{array}{l}E \\
\text { مִ } \\
\text { No }\end{array}$ & $\begin{array}{l}\varepsilon \\
\text { E }\end{array}$ & $\begin{array}{l}\varepsilon \\
\text { E }\end{array}$ & $\frac{\varepsilon}{\stackrel{\Sigma}{N}}$ & 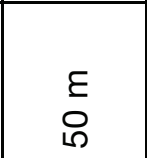 & $\begin{array}{l}\varepsilon \\
\circ \\
\circ\end{array}$ & $\begin{array}{l}\varepsilon \\
\text { 巨. }\end{array}$ & $\begin{array}{l}\varepsilon \\
\text { E }\end{array}$ & 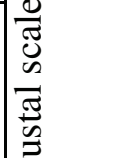 \\
\hline 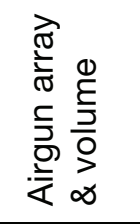 & 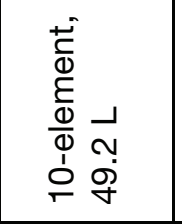 & $\begin{array}{l}-1 \\
m \\
\infty \\
\infty \\
\circ\end{array}$ & $\begin{array}{l}-1 \\
\stackrel{N}{o} \\
\stackrel{\infty}{N}\end{array}$ & $\begin{array}{l}-1 \\
\stackrel{N}{0} \\
\stackrel{\infty}{N}\end{array}$ & $\begin{array}{l}\vec{J} \\
\stackrel{+}{+} \\
\text { D. }\end{array}$ & 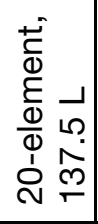 & 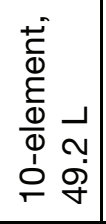 & 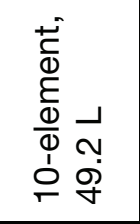 & 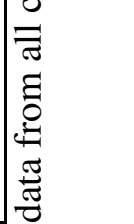 \\
\hline 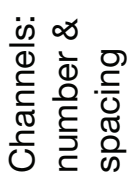 & $\begin{array}{l}\stackrel{0}{i} \\
\stackrel{+}{+} \\
\stackrel{\infty}{\infty} \\
\stackrel{\infty}{+} \varepsilon\end{array}$ & $\begin{array}{l}\varepsilon \\
\stackrel{2}{N} \\
\stackrel{\circ}{N} \\
\stackrel{-}{c}\end{array}$ & $\begin{array}{l}\varepsilon \\
\stackrel{E}{N} \\
\text { J } \\
\stackrel{f}{L}\end{array}$ & $\begin{array}{l}E \\
\stackrel{E}{N} \\
\text { J } \\
\stackrel{f}{L}\end{array}$ & $\begin{array}{l}\varepsilon \\
\circ \\
⺊ \\
\infty \\
\infty\end{array}$ & $\begin{array}{l}\varepsilon \\
\stackrel{\varepsilon}{0} \\
\stackrel{0}{0} \\
\stackrel{0}{c}\end{array}$ & 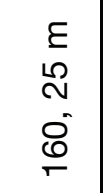 & $\begin{array}{l}\varepsilon \\
\sim \\
\stackrel{0}{0} \\
\stackrel{0}{\sigma}\end{array}$ & 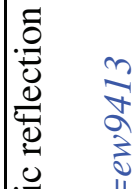 \\
\hline 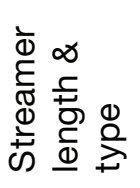 & $\frac{\xi}{\dot{\varepsilon}} \frac{\bar{\pi}}{\frac{\pi}{\sigma}}$ & 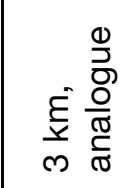 & 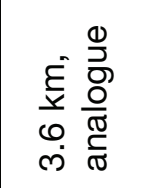 & 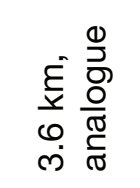 & 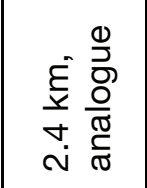 & 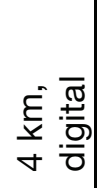 & 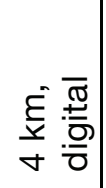 & 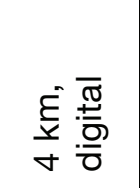 & 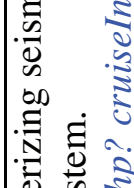 \\
\hline 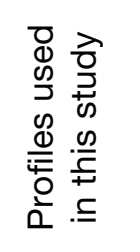 & 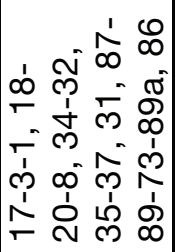 & 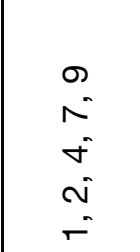 & $\stackrel{10}{\Gamma}$ & $\begin{array}{l}\text { m } \\
\stackrel{+}{N} \\
\infty\end{array}$ & 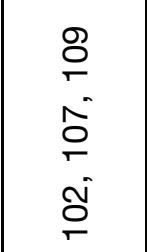 & 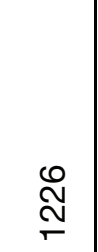 & $\begin{array}{l}1 \\
0 \\
0\end{array}$ & 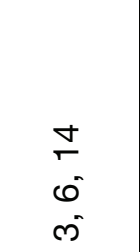 & 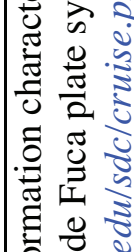 \\
\hline 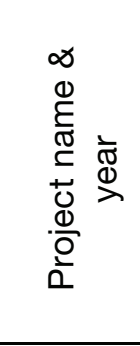 & 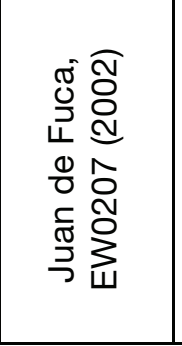 & 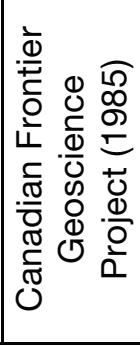 & 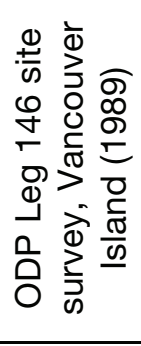 & 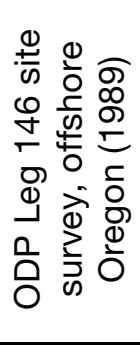 & 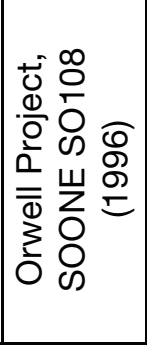 & 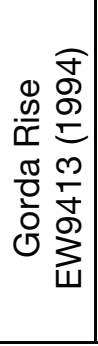 & 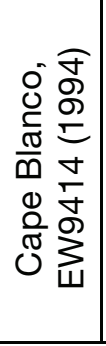 & 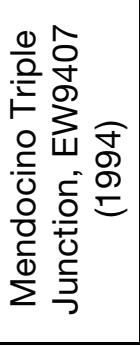 & 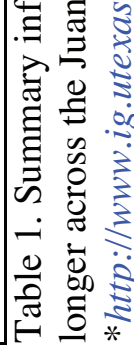 \\
\hline
\end{tabular}

